\title{
Determinants for Consumer Choice of "Electronic Banking Utilization"; Evidence from Customers of Public Banks in Sri Lanka
}

\author{
K.S. Madhushankha ${ }^{1}$ and R. Senathiraja ${ }^{2}$ \\ ${ }^{I}$ Department of Management and Organization Studies, University of Colombo, Sri Lanka \\ ${ }^{2}$ Faculty of Management and Finance, University of Colombo, Sri Lanka
}

\begin{abstract}
Electronic banking facilities are no longer competitive advantages but competitive necessities for banks to compete. Even the banks provide a vast body of electronic banking facilities; customers are not utilizing those facilities to the extent bank expected. However, a limited number of empirical studies have been published on electronic banking utilization; this study seeks to find the determinants for utilization of Electronic banking facilities provided by state banks for their customers in Sri Lanka?" The study is based on a quantitative approach to identify factors affecting electronic banking utilization. Individual factors, service quality, user input factors, price factor, service product characteristics \& perceived risk were identified as the determinant factors as the findings. Further, it reveals different relationships and provides findings that support, confirm or contradict previous studies.
\end{abstract}

Keywords: Electronic banking, Service quality, User input factors, Individual factors, Perceived risk Sri Lanka

\section{INTRODUCTION}

$\mathrm{T}$ The banking industry is rapidly responding according to the changes in customer needs and customer preferences. Factors like increasing competition, social trends, information technology developments, and financial sector regulations are significantly contributing to this rapid response of the banking sector (Giannakoudi, 1999; Byers \& Lederer, 2001; Marakarkandy, Yajnik \& Dasgupta,2017, Islam, Jebarajakirthy \& Shankar, 2021). Based on management anticipations and reactions for change, the success of retail banks varies. Electronic banking facilities like online banking, with the support of new technology, have defeated the traditional banking delivery methods. There are more

\section{Problem Statement}

$>$ What are the determinants for the utilization of Electronic banking facilities provided by state banks for their customers in Sri Lanka?

Literature has featured numerous published research papers, articles, and books to address the above issue in different countries worldwide. (Pyun et al., 2002; Hendrikse and Christiaanse, 2000; Mols, 1998). Nevertheless, there are not much studies have been done in the Sri Lankan context. The researcher has identified that empirical gap in this area and developed the study's objective to identify the determinants advantages of electronic banking over personal-customer banking.

Adopting information technology in core business functions of the banking sector was commenced in the late 1980s'. Subsequently, the internet and was available for commercial works by the early 1990s. In Sri Lanka, Sampath Bank became the pioneer in electronic banking by introducing ATM (Automated Teller Machine) facilities. Subsequently, in 1989 they introduced the uni-bank system where customers can freely access their bank accounts through any branch. These two events radicalized the local banking sector and the electronic transaction history. After that, in 1989, the international payment solution Master card was introduced to Sri Lankan customers, thus opening the world's market. Finally, these three milestones together revolutionized the local banking sector and paved the path for a new electronic era.

The literature is comprised of numerous studies related to electronic banking (Alalwan, Dwivedi \& Williams, 2016; Safeena, Kammani \& Date 2018; Šalčiuvienè, Auruškevičienė \& Ivanauskienè, 2014, Yi, Zainuddin \& Bakar, 2021). This study was carried out to examine consumer decision-making on electronic banking utilization over traditional banking in Sri Lanka. The researcher has operationalized the determinant factors as service quality factors, individual factors, price factors, risk factors, service product characteristics, and user input factors affecting the consumer choice of electronic banking utilization by using the consumer decision-making framework.

for utilization of electronic banking facilities provided by state banks for their customers in Sri Lanka. Previous literature has employed the consumer decision-making model that the researcher utilizes to test the argument of their studies (Gan et al., 2006).

Even the research problem identified by the researcher is supported and justified by previous literature in different countries. The researcher has carried out a preliminary study using 30 Sri Lankan state banks customers to understand the level of utilization of electronic banking facilities. From that preliminary study, the researcher has evidence of the 
identified research problem's absolute validity and actual existence in the Sri Lankan context. The study results revealed that only six point seven percent of customers from the selected sample were generally using online banking facilities available for their standard requirements. In addition, only twenty-six point seven percent of customers frequently used debit cards and credit cards for their daily transactions and six point seven percent of customers from the selected sample were transferring their money through electronic banking facilities. Hence, online banking, payments through credit or debit cards, and virtual money transfers are considered central elements of facilities provided by the banks under electronic banking facilities; it is proven that their level of utilization of those electronic banking facilities is superficial. Even it is not studied previously in the Sri Lankan banking sector researcher has developed the study to fill that empirical gap that exists in the Sri Lankan context to determine the factors that influence the utilization of electronic banking facilities provided by the state banks for their customers in Sri Lanka.

\section{LITERATURE REVIEW}

\section{The Consumer Decision-making Framework}

The consumer decision-making framework originated by Dewey (1910) suggests the five stages of the consumer decision-making process: problem recognition, search and evaluation of alternatives, choice, and outcome-based on consumer purchasing behavior headed for goods and services. This framework identifying the consumer as an information processor analyzes information through the different stages of the decision-making process. So that it suggests the consumer decision-making process is theoretically applicable for a full range of consumer decisions. The framework was adopted by Engel et al. (1973), Block and Roering (1976) and extended and related it to the problem-solving process. At any instance that the consumer redefines the initial problem, search for new information, or to re-evaluate potential problem solutions will be discontinued due to their desired or actual decision-making status support by decision-making framework Moreover, the impact made by environmental factors; income, cultural, family, social and physical factors also constraints for various stages in the consumer decision-making process.
Dewey's consumer decision-making process for goods was applied by Zeithaml and Bitner (2003) to the service segment. The process was operationalized as; need recognition, information search, evaluation of alternatives, purchases, and consumption post-purchase evaluation. The variables that consumers use to evaluate service alternatives come in many forms. The number of variables involved and how they influence consumers' evaluation of alternatives varies according to the type of situation (Loundon \& Bitta, 1993; Agwu, 2016). The literature suggests that service quality factors, individual factors, price factors, risk factors, service product factors, and user input factors are relevant determinants for the consumers' decision-making between electronic and non-electronic banking (see Figure 1).

Determinant factors for utilization of electronic banking facilities

Service quality dimension, perceived risk factors, user input factors, price factors, service product characteristics, and individual factors are the main factors that determine consumer choice of electronic banking utilization (Gan et al., 2006; Alalwan et al.,2018). We can define service quality as a critical success factor for an organization that helps them increase their competitiveness and build their competitive advantage (Ling et al., 2016; Amin, 2016). Under this concept, three primary dimensions can be identified: assurance, reliability, and responsiveness. Reliability and use of electronic banking have a positive relationship (Liao \& Cheung, 2002; Gerrard \& Cunningham, 2003; Alalwan, Dwivedi \& Rana, 2017). Literature has shown that the assurance dimension is also an important dimension under service quality characteristics.(Polatoglu \& Ekin, 2001; Cheung, 2002).To encourage customers to demand the highest quality, the nature of services impacts much. It is essential to be very close to customers to capture customers' information, expectations, and perceptions. (Prakash, 2019; Tabash et al., 2019; Khan, Zubair\& Malik, 2019). Electronic banking users believe, other than traditional ways of banking, electronic banking responded to their needs. ( Boruah, 2018; Falkovitch, 2020). Gerrard \& Cunningham(2003), Asad, Mohajerani, and Nourseresh (2016) show that the speed to the response from electronic banking and fast access to banking transactions are important factors in consuming electronic banking 


\section{Consumer Decision-Making Process}

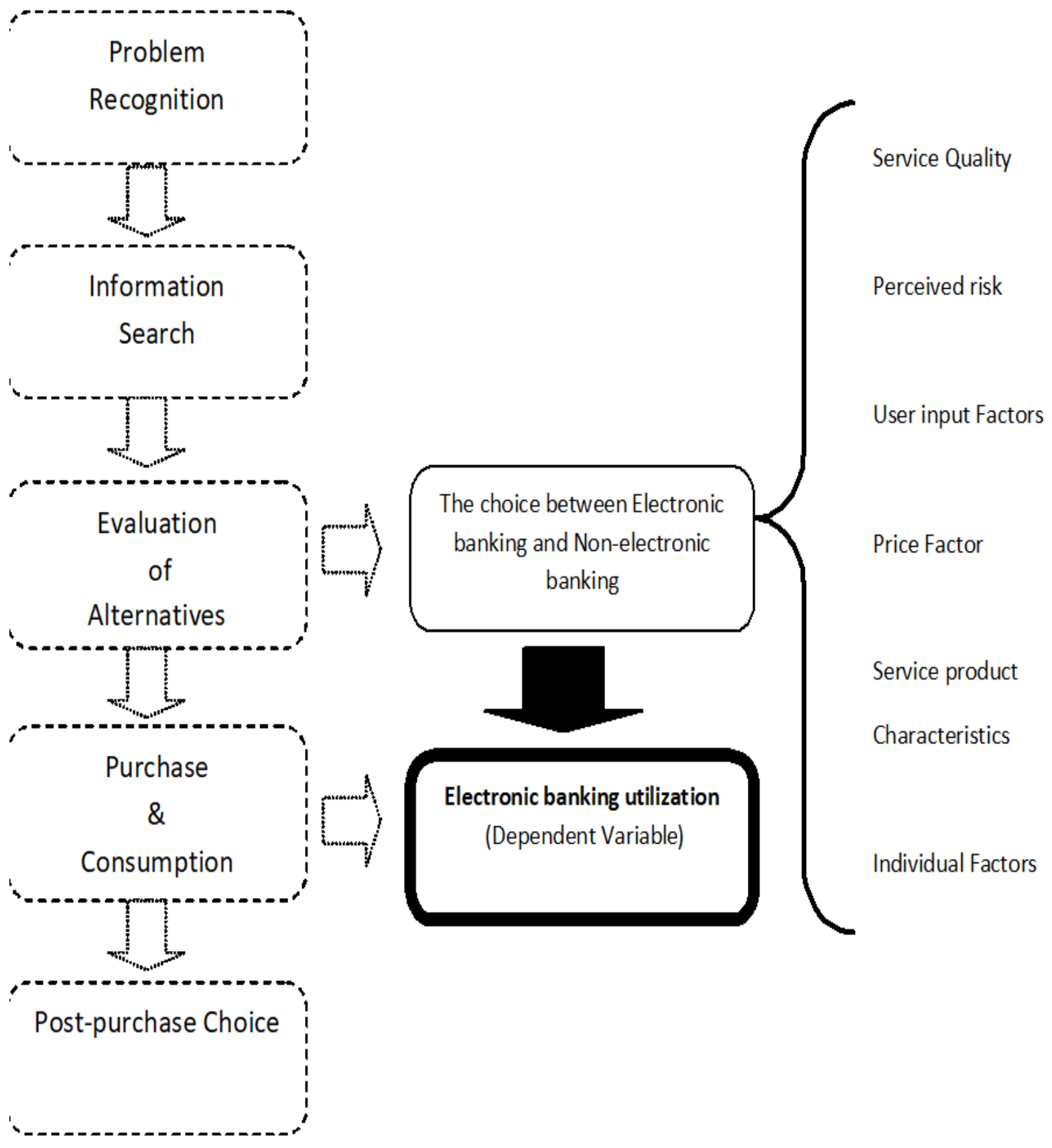

Fig .I Consumer Decision Making Framework

Consumers perceive greater risk when they are buying services other than tangible goods. (Clow, Baack \&Fofliasso, 1998; Agwu, 2016). A similar study shows that the goods are intangible, non-standardized, and often sold without guarantee or warranties (Zeithaml, 1981; Babić et al., 2016; Elliott et al., 2015). Hence technology-enabled services exhibit unfamiliar and ambiguous stimuli, and the consumer thinks electronic banking is a riskier technology-enabled channel for their banking transactions. (Davidow, 1986; Mudie \& Pirrie, 2012). Under perceived risk, we can identify six main dimensions: psychological risk, social risk, time risk, quality risk, financial risk, and physical risk. (Lockett \&Littler, 1997; Gan et al., 2006; Marakarkandy, Yajnik, \& Dasgupta, 2017) Under those dimensions, consumers' risk perceptions are different from 
customer to customer (Zhao, Lloyd, \& Goode, 2008; Hampshire, 2017). The perceived quality of the service impacts perceived risk. Similarly, the author points out that reliability and empathy of service mainly influence financial and psychological risks, but tangible cues of service quality principally influence functional and social risks. However, higher levels of acceptance of risk and self-confidence mitigate the detrimental effects of perceived risk on intention to use electronic banking (Marafon, Basso, Espartel, de Barcellos, \& Rech, 2018).

Control, enjoyment, and intention have been identified as variables to test user input factors affecting electronic banking utilization. (Gan et al., 2006). Each every bank imposes specific mandates and requirements under their responsibilities regulatory oversight. So control is an essential factor that consumers concern about when they use electronic banking. (Mantel, 2000; Hernandez, Jonker \& Kosse, 2017)Because of that, banks should create adequate "controls" designed to fill security gaps (Guracech\& Gregory, 2013). When proposing controls, the bank should consider customers as well. Guracech\& Gregory (2013) identified that user control, such as the amount of control or contribution involved in electronic banking transactions was a significant determinant for consumers' decision to use electronic banking.

Similarly, Bateson (1985) identify that consumers chose to use technology-based channels in the delivery of a service, not because of the monetary incentives, but because they perceived a stronger sense of control as a result of a selfservice option (Bateson, 1985; Zhu et al., 2013). If they utilize electronic banking, control in electronic banking relates to the consumers' perceived involvement or sense of control. Mantel, 2000 says that the control attribute is also one of the most aspects that customers consider when choosing electronic banking facilities. Similarly, Liao \& Cheung (2002) says that user control is a significant determinant for consumer decision-making choosing electronic banking. Sathye (1999), Alalwan, Dwivedi, and Rana (2017), Gerrard and Cunningham (2003) studies are making their suggestions on consumers' intention to use electronic banking was positively related to the usage of electronic banking. "Greater user control comes at a price - often that of greater complexity and increased effort"(Xie \& Cool, 2000). Enjoyment is also becoming a considerable positive predictor of customers' intentions to repurchase (Chiu, Chang, Cheng, \& Fang, 2009; Frame, Wall \& White, 2018).

The price factor can be identified as perceived relative economic advantages; consumers were motivated to use electronic banking facilities (Sathye, 1999, Alalwan, Dwivedi \& Rana, 2017). Similarly, it argues that two types of prices, including bank costs and other charges, were accounted for internet banking. Sathye (1999) identified that the higher price paid by consumers negatively impacted the positive choice of electronic banking. Generally, service product characteristics comprise service features, targets of service, and core service. Polatoglu and Ekin,( 2001),Karjaluoto, Mattila, and pento, (2002) and Liébana-Cabanillas, Sánchez-Fernández and Muñoz-Leiva, (2014) studies found that the positive relationship between service product characteristics and utilization of electronic banking facilities. Considering individual factors lifestyle of an electronic banking customer is different from customers who do not use electronic banking facilities. That can be called an e-life style ( $\mathrm{Yu}, 2015$; Asongu, Nwachukwu \& Aziz, 2018; Lin \& Fu, 2018; Changchit et al., 2020). Similarly, the author points this e lifestyle changes their attitudes on building relationships with banking facilities. The knowledge of electronic banking that consumers have is a crucial factor under electronic banking utilization (Clow, Baack, \& Fofliasso, 1998). Consumer resources also influence electronic banking(Mols, 1998; Firdous \& Farooqi, 2017). Similarly, it shows that lacked access to personal computers prohibited the adaptation to electronic banking as well. Furthermore, the studies confirm that individual factors are positively related to the choice of electronic banking utilization.

\section{METHODOLOGY}

\section{Research approach}

Based on the purpose of the study research approach can be experimental, quasi-experimental, quantitative, qualitative, or mixed. A qualitative study does not include variables, while a quantitative study includes dependent and independent variables. Service quality, perceived risk, User input factors, Price factor, Service product characteristics, and Individual factors have been taken as independent variables for the study. In contrast, the utilization of electronic banking has been taken as the dependent variable. To fulfill the purpose of the study, the researcher analyzes the relationship between independent and dependent variables through a quantitative research approach to obtain statistical solutions focusing on numbers derived from randomly distributed questionnaires among banking customers. It must be noted that although the researcher can carry out the study using an experimental research approach, it is not applicable for this study. Because the experimental approach, a set of variables is kept constant while the other variables are being measured under that condition. However, in this study, electronic banking utilization changes from customer to customer, and the factors vary continuously. Hence no variables can be considered consider constant. Due to this reason, the researcher has used a quantitative approach for the study 


\section{Conceptual Model}

\begin{tabular}{|l|l|}
\hline Independent variables & \\
\hline Service quality & \\
\hline Perceived risk & \\
\hline Service product \\
characteristics
\end{tabular}

Fig II. The conceptual model for the study

Based on the arguments in the previous literature and the conceptual framework for the study, the following were hypothesized,

$\mathrm{H}_{0}$ : Service quality does not affect utilization of electronic banking facilities

$\mathrm{H}_{1}$ : Service quality affects utilization of electronic banking facilities

$\mathrm{H}_{0}$ : Perceived risk does not affect the utilization of electronic banking facilities.

$\mathrm{H}_{1}$ : Perceived risk affects utilization of electronic banking facilities.

$\mathrm{H}_{0}$ : User input factor does not affect utilization of electronic banking facilities

$\mathrm{H}_{1}$ : User input factor affects utilization of electronic banking facilities

$\mathrm{H}_{0}$ : Price factor does not affect on utilization of electronic banking facilities

$\mathrm{H}_{1}$ : Price factor affects utilization of electronic banking facilities

$\mathrm{H}_{0}$ : service product characteristic factor does not affect on utilization of electronic banking facilities.

$\mathrm{H}_{1}$ : service product characteristic factor affects the utilization of electronic banking facilities.
$\mathrm{H}_{0}$ : Individual factors does not affect utilization of electronic banking facilities.

$\mathrm{H}_{1}$ : Individual factor affects utilization of electronic banking facilities.

\section{Operationalization}

The study was operationalized to examine the relationship between the independent variables and the dependent variable, as follows,

Table I: Independent variable Operationalization

\begin{tabular}{|c|c|c|c|}
\hline Concept & Dimensions & Scale & Indicator \\
\hline \multirow[t]{7}{*}{$\begin{array}{l}\text { Service } \\
\text { Quality }\end{array}$} & Reliability & SQR1 & $\begin{array}{l}\text { Transaction through } \\
\text { electronic banking are } \\
\text { accurate }\end{array}$ \\
\hline & & SQR2 & $\begin{array}{c}\text { Transaction through } \\
\text { electronic banking are } \\
\text { reliable }\end{array}$ \\
\hline & Assurance & SQA 1 & $\begin{array}{l}\text { Electronic Banking } \\
\text { offers high security }\end{array}$ \\
\hline & & SQA2 & $\begin{array}{l}\text { I am familiar with } \\
\text { electronic Banking }\end{array}$ \\
\hline & & SQA3 & $\begin{array}{l}\text { I am comfortable with } \\
\text { electronic Banking }\end{array}$ \\
\hline & & SQA4 & $\begin{array}{l}\text { I have had satisfactory } \\
\text { experiences with } \\
\text { electronic Banking }\end{array}$ \\
\hline & Responsiveness & SQr1 & $\begin{array}{l}\text { Electronic Banking } \\
\text { services are faster than } \\
\text { in branch Banking }\end{array}$ \\
\hline
\end{tabular}




\begin{tabular}{|c|c|c|c|}
\hline & & SQr2 & $\begin{array}{c}\text { Electronic Banking } \\
\text { Provide easy access to } \\
\text { banking Transactions }\end{array}$ \\
\hline \multirow[t]{7}{*}{$\begin{array}{l}\text { Perceived } \\
\text { Risk }\end{array}$} & $\begin{array}{l}\text { Psychological } \\
\text { Risk }\end{array}$ & PRP1 & $\begin{array}{c}\text { I feel in branch banking } \\
\text { is not consist with } \\
\text { myself image }\end{array}$ \\
\hline & Social Risk & PRS1 & $\begin{array}{l}\text { I Believe my friends } \\
\text { will disapprove if I } \\
\text { change to in branch } \\
\text { banking }\end{array}$ \\
\hline & Time Risk & PRT1 & $\begin{array}{l}\text { Travelling to a Bank } \\
\text { branch involves too } \\
\text { much time }\end{array}$ \\
\hline & & PRT2 & $\begin{array}{l}\text { Travelling to a Bank } \\
\text { branch involves too } \\
\text { much queuing time }\end{array}$ \\
\hline & Quality Risk & PRQ1 & $\begin{array}{l}\text { In Branch Banking is } \\
\text { less Satisfying than } \\
\text { electronic banking }\end{array}$ \\
\hline & Physical Risk & PRp1 & $\begin{array}{c}\text { Going to bank may } \\
\text { result in physical } \\
\text { damages due to } \\
\text { terrorist attack. }\end{array}$ \\
\hline & & PRp2 & $\begin{array}{l}\text { In Branch Banking may } \\
\text { results in Physical } \\
\text { injury due to robbery }\end{array}$ \\
\hline \multirow[t]{5}{*}{$\begin{array}{l}\text { User input } \\
\text { Factors }\end{array}$} & Control & UI1 & $\begin{array}{l}\text { I like to use Electronic } \\
\text { Banking because it } \\
\text { offers independence }\end{array}$ \\
\hline & & UI2 & $\begin{array}{l}\text { Electronic Banking } \\
\text { enables me to be fully } \\
\text { involved in my banking } \\
\text { transactions }\end{array}$ \\
\hline & Enjoyment & UIE1 & $\begin{array}{l}\text { Electronic Banking is } \\
\text { very enjoyable to use }\end{array}$ \\
\hline & & UIE2 & $\begin{array}{c}\text { Electronic Banking is } \\
\text { user Friendly }\end{array}$ \\
\hline & Intention & UII1 & $\begin{array}{c}\text { I like to use new } \\
\text { methods to conduct } \\
\text { banking transactions }\end{array}$ \\
\hline Price Factor & Price & PF1 & $\begin{array}{c}\text { Electronic Banking } \\
\text { Charges are expensive }\end{array}$ \\
\hline \multirow[t]{3}{*}{$\begin{array}{c}\text { Service } \\
\text { Product } \\
\text { characteristics }\end{array}$} & $\begin{array}{c}\text { Service } \\
\text { Product } \\
\text { characteristics }\end{array}$ & SPE1 & $\begin{array}{l}\text { Electronic Banking is } \\
\text { time saving }\end{array}$ \\
\hline & & SPE2 & $\begin{array}{l}\text { Customer services in } \\
\text { Electronic banking has } \\
\text { a consist standard }\end{array}$ \\
\hline & & SPE3 & $\begin{array}{c}\text { Electronic Banking Has } \\
\text { a wide variety of } \\
\text { service available }\end{array}$ \\
\hline \multirow[t]{5}{*}{$\begin{array}{l}\text { Individual } \\
\text { Factors }\end{array}$} & $\begin{array}{l}\text { Consumer } \\
\text { Resources }\end{array}$ & IFC1 & $\begin{array}{c}\text { I have regular access to } \\
\text { a computer }\end{array}$ \\
\hline & & IFC2 & $\begin{array}{c}\text { I have regular access to } \\
\text { a internet }\end{array}$ \\
\hline & & IFC3 & $\begin{array}{l}\text { Electronic banking is } \\
\text { easy to use }\end{array}$ \\
\hline & Life style & IFL1 & $\begin{array}{l}\text { I use electronic } \\
\text { Banking because my } \\
\text { friends use it }\end{array}$ \\
\hline & & IFL2 & $\begin{array}{l}\text { The Use of Electronic } \\
\text { Banking reflects my } \\
\text { social status }\end{array}$ \\
\hline
\end{tabular}

Table II. Dependent variable operationalization

\begin{tabular}{|c|c|c|}
\hline $\begin{array}{c}\text { Utilization of } \\
\text { Electronic Banking } \\
\text { Facilities }\end{array}$ & D1 & $\begin{array}{c}\text { Genarally I use electronic banking } \\
\text { facilities that are available, for my } \\
\text { everyday requirements }\end{array}$ \\
\hline & D2 & $\begin{array}{c}\text { I use Credit/Debit cards for most of my } \\
\text { Payments. }\end{array}$ \\
\hline & D3 & $\begin{array}{c}\text { I transfer money through Electronic } \\
\text { banking facilities frequently. }\end{array}$ \\
\hline
\end{tabular}

\section{Population and sample}

The sample was excluded from the customers who are not registered for electronic banking facilities. The study population can be defined as the customers of public banks, Bank of Ceylon, Peoples Bank, and National Savings Bank in western provinces with electronic banking facility access. The western province of Sri Lanka has been selected as the geographical area for the study. The most densely populated province of Sri Lanka, which is 3,593 square kilometers in extent, is home to the country's legislative capital Sri Jayewardenepura. It is also home to the country's commercial hub. It covers around $30 \%$ of the total population of Sri Lanka, which was a considerable amount; hence there are nine provinces in Sri Lanka. Under that, we take 300 people in the western province who registered in electronic banking facilities. The convenient sampling method is using to build the sample because of the easiness and quick data gathering.

The sample is tested by serving printed questionnaires among public bank customers, and it is printed from both languages in Sinhala and English and distributed randomly. To analyze and interpret data Likert scale method is used. Five point ordinal scale is used for this study, and the questions were phrased in the form of statements scored as $1=$ highly agree, 2 = agree, $3=$ neutral, $4=$ disagree, and $5=$ highly disagree. The questionnaire gathered information on consumer's decisions to use electronic banking versus non-electronic banking. Questionnaires were distributed and collected directly by the researcher for the study by visiting the main branches of each bank in Colombo, Gampaha, and Kaluthara. Three hundred and fifty (350) questionnaires were distributed, and from that, 300 questionnaires, complete and filled with a good understanding of the purpose, were selected as the sample for the study.

\section{DATA PRESENTATION AND ANALYSIS}

The researcher has used descriptive statistics, reliability test statistics, correlation and multiple regression statistics, oneway ANOVA statistics, normality statistics, independent sample test statistics, group statistics, and multiple comparison statistics to check the research validity. Correlation and multiple regression models were used to identify the factors affecting on utilization of electronic banking and facilities provided by the public banks in Sri Lanka. 
Table III. Profile of Respondents

\begin{tabular}{|c|c|c|c|}
\hline Item & & Frequency & Valid Percentage \\
\hline \multirow[t]{3}{*}{ Gender } & Male & 142 & 47.3 \\
\hline & Female & 158 & 52.7 \\
\hline & Total & 300 & \\
\hline \multirow[t]{4}{*}{ Age } & $18-30$ years & 137 & 45.7 \\
\hline & $31-50$ years & 108 & 36.0 \\
\hline & above 50 & 55 & 18.3 \\
\hline & Total & 300 & \\
\hline \multirow[t]{5}{*}{$\begin{array}{c}\text { Marital } \\
\text { status }\end{array}$} & Married & 121 & 40.3 \\
\hline & Unmarried & 172 & 57.3 \\
\hline & Widowed & 05 & 1.7 \\
\hline & Divorced & 02 & 7.0 \\
\hline & Total & 300 & \\
\hline \multirow[t]{5}{*}{ Profession } & $\begin{array}{c}\text { Gov } \\
\text { employee }\end{array}$ & 57 & 19.0 \\
\hline & $\begin{array}{c}\text { Pvt } \\
\text { employee }\end{array}$ & 127 & 42.3 \\
\hline & Business & 37 & 12.3 \\
\hline & Student & 79 & 26.3 \\
\hline & Total & 300 & \\
\hline \multirow[t]{5}{*}{ Income } & $\begin{array}{l}\text { Up to } \\
10000\end{array}$ & 119 & 39.7 \\
\hline & $\begin{array}{l}10000- \\
25000\end{array}$ & 73 & 24.3 \\
\hline & $\begin{array}{c}25000- \\
40000\end{array}$ & 61 & 20.3 \\
\hline & $\begin{array}{l}\text { Above } \\
40000 \\
\end{array}$ & 47 & 15.7 \\
\hline & Total & 300 & \\
\hline
\end{tabular}

\section{Reliability analysis}

The researcher carried out a reliability analysis before the variables are operationalized. Cronbach's alpha has been applied to determine the internal consistency as several items have been used to operationalized one variable. Then service quality, perceived risk, user input factors, price factor, service product characteristics, and individual factors have been operationalized using several items. Therefore, reliability analysis has been carried out to determine their internal consistency and direction. Each item's

Alpha scores to test each dimension were totaled, and a mean score was calculated for each dimension. Cronbach's alpha figures have been provided (see table 4). Value of 0.6 was taken as the cut-off point for the reliability. Churchill (1979) empirically supports that value of 0.6 or more indicates the satisfactory internal consistency reliability of the items taken to test each dimension in the study. Hence all the values are more than 0.6. Therefore, there is internal consistency, variables are following the same direction, construct, and the concept can be correctly measured.
Table IV. Cronbach Alpha Reliability Test

\begin{tabular}{|c|c|c|c|}
\hline Concept & Dimension & Questions & $\begin{array}{c}\text { Cronbach's } \\
\text { alpha } \\
\text { figure } \\
\end{array}$ \\
\hline \multirow[t]{3}{*}{ Service quality } & Reliability & SQR 1,SQR 2 & 0.776 \\
\hline & Assurance & $\begin{array}{c}\text { SQA 1,SQA } \\
\text { 2,SQA 3,SQA } 4\end{array}$ & 0.872 \\
\hline & Responsiveness & SQr 1,SQr 2 & 0.719 \\
\hline \multirow[t]{6}{*}{ Perceived risk } & Psychological & PRP 1 & N/A \\
\hline & Social risk & PRS 1 & N/A \\
\hline & $\begin{array}{c}\text { Traveling time } \\
\text { risk }\end{array}$ & PRT 1 & N/A \\
\hline & Quing time risk & PRT 2 & N/A \\
\hline & Quality risk & PRQ 1 & N/A \\
\hline & Physical risk & PRp 1, PRp 2 & 0.629 \\
\hline \multirow[t]{3}{*}{$\begin{array}{l}\text { User input } \\
\text { factors }\end{array}$} & Control & UI 1, UI 2 & 0.638 \\
\hline & Enjoyment & UIE 1 , UIE 2 & 0.737 \\
\hline & Intension & UII 1 & N/A \\
\hline Price factor & Price & PF 1 & N/A \\
\hline $\begin{array}{c}\text { Service } \\
\text { product } \\
\text { characteristics }\end{array}$ & Service product & $\begin{array}{l}\text { SPE 1, SPE 2, } \\
\text { SPE } 3\end{array}$ & 0.760 \\
\hline \multirow[t]{2}{*}{$\begin{array}{c}\text { Individual } \\
\text { factors }\end{array}$} & $\begin{array}{l}\text { Consumer } \\
\text { resources }\end{array}$ & $\begin{array}{c}\text { IFC 1, IFC 2, IFC } \\
3\end{array}$ & 0.872 \\
\hline & Lifestyle & IFL 1 , IFL 2 & 0.672 \\
\hline
\end{tabular}

The factors that influence utilization of electronic banking facility

Table V: Correlation Analysis

\begin{tabular}{|c|c|c|}
\hline & & Utilization \\
\hline \multirow{3}{*}{ Service Quality } & Pearson Correlation & $.681^{* *}$ \\
\hline & Sig. (2-tailed) & .000 \\
\hline & $\mathrm{N}$ & 300 \\
\hline \multirow{3}{*}{ Perceived risk } & Pearson Correlation & $.632^{* *}$ \\
\hline & Sig. (2-tailed) & .000 \\
\hline & $\mathrm{N}$ & 300 \\
\hline \multirow{3}{*}{ User inputs } & Pearson Correlation & $.673^{* *}$ \\
\hline & Sig. (2-tailed) & .000 \\
\hline & $\mathrm{N}$ & 300 \\
\hline \multirow{3}{*}{ Price } & Pearson Correlation & $-.357^{* *}$ \\
\hline & Sig. (2-tailed) & .000 \\
\hline & $\mathrm{N}$ & 300 \\
\hline \multirow{3}{*}{$\begin{array}{l}\text { Service Product } \\
\text { characteristics }\end{array}$} & Pearson Correlation & $.540^{* *}$ \\
\hline & Sig. (2-tailed) & .000 \\
\hline & $\mathrm{N}$ & 300 \\
\hline \multirow{3}{*}{ Individual factors } & Pearson Correlation & $.770^{* *}$ \\
\hline & Sig. (2-tailed) & .000 \\
\hline & $\mathrm{N}$ & 300 \\
\hline
\end{tabular}


Hence correlation analysis is a bivariate analysis. The researcher has considered the combined effect of all these factors by applying a multiple regression model to determine the significant factors that affect electronic banking utilization. According to the multiple regression model, the model summary is provided by,

Table VI. Model Summary

\begin{tabular}{|c|c|c|c|c|}
\hline Model & $\mathrm{R}$ & $\begin{array}{c}\mathrm{R} \\
\text { Square }\end{array}$ & $\begin{array}{c}\text { Adjusted R } \\
\text { Square }\end{array}$ & $\begin{array}{c}\text { Std. Error of } \\
\text { the Estimate }\end{array}$ \\
\hline 1 & $.803^{\mathrm{a}}$ & .644 & .637 & .62401 \\
\hline \multicolumn{3}{|c|}{ b. Dependent Variable: Utilization } \\
\hline
\end{tabular}

The coefficient of determination $\mathrm{R}$ Square is 0.644. This indicates that the model has covered $64.4 \%$ of the dependent variable, the utilization of electronic banking facilities. As the value is more than sixty percent, the model is nicely fitted. According to $\mathrm{R}$, which is multiple correlations, the coefficient is 0.803 . It indicates how independent variables are jointly correlated with the dependent variable, which is electronic banking utilization. As the value is more than 0.7 there is a robust joint association between factors affecting utilization and the utilization of electronic banking facilities.

Table VII: Collinearity Statistics

\begin{tabular}{|c|c|c|}
\hline \multirow{2}{*}{ Model } & \multicolumn{2}{|c|}{ Collinearity Statistics } \\
\cline { 2 - 3 } & Tolerance & VIF \\
\hline Service_Quality & .333 & 3.000 \\
\hline Perceived_risk & .367 & 2.724 \\
\hline User_inputs & .280 & 3.578 \\
\hline Price & .747 & 1.339 \\
\hline Service product & .335 & 2.982 \\
\hline Individual_factors & .322 & 3.109 \\
\hline
\end{tabular}

According to the collinearity statistics, all the VIF values are less than five. It indicates that all the determinant factors are jointly significant. According to the regression ANOVA table provided below, sig. value of the F statistic is 0.00 . It is highly significant and confirmed that the model is jointly significant. It indicates that all the determinant factors jointly influence the utilization of electronic banking facilities.

Table VII: Regression ANOVA Table

\begin{tabular}{|c|c|c|c|c|c|c|}
\hline \multicolumn{7}{|c|}{ ANOVA } \\
\hline \multicolumn{2}{|c|}{ Model } & $\begin{array}{c}\text { Sum of } \\
\text { Squares }\end{array}$ & df & $\begin{array}{c}\text { Mean } \\
\text { Square }\end{array}$ & F & Sig. \\
\hline \multirow{2}{*}{1} & $\begin{array}{c}\text { Regressi } \\
\text { on }\end{array}$ & 206.581 & 6 & 34.430 & $\begin{array}{c}88.42 \\
2\end{array}$ & $.000^{\mathrm{a}}$ \\
\cline { 2 - 7 } & Residual & 114.090 & 293 & .389 & & \\
\cline { 2 - 7 } & Total & 320.671 & 299 & & & \\
\hline \multicolumn{7}{|c|}{ a. Predictors: (Constant), Individual, Price, Perceived_risk, Service, } \\
Service_Quality, User_inputs
\end{tabular}

Table IX. Correlation Coefficients

\begin{tabular}{|c|c|c|c|}
\hline \multirow{2}{*}{ Model } & \multicolumn{2}{|c|}{ Unstandardized Coefficients } & \multirow{2}{*}{$\begin{array}{c}\begin{array}{c}\text { Standardized } \\
\text { Coefficients }\end{array} \\
\text { Beta } \\
\end{array}$} \\
\hline & $\mathrm{B}$ & Std. Error & \\
\hline $\begin{array}{c}\text { Service_Qu } \\
\text { ality }\end{array}$ & .300 & .079 & .229 \\
\hline $\begin{array}{c}\text { Perceived_ri } \\
\text { sk }\end{array}$ &.-.050 & .011 & -.026 \\
\hline User_inputs & .162 & .081 & .132 \\
\hline Price &.- .117 & .038 & -.125 \\
\hline $\begin{array}{l}\text { Service } \\
\text { product }\end{array}$ &.- .109 & .069 & -.096 \\
\hline $\begin{array}{c}\text { Individual_f } \\
\text { actors }\end{array}$ & .570 & .065 & .543 \\
\hline
\end{tabular}

The beta value received for service quality is 0.229 , indicating a considerable effect on utilization. Similarly, other variables also have received noticeably significant beta values proving their effect on the utilization of electronic banking facilities.

The researcher has used this correlation coefficient to test the hypotheses developed, which again confirms the results obtained in the bivariate correlation analysis mentioned above. So that all the null hypotheses are rejected, concluding that all the independent variables affect electronic banking utilization.

Further, the results obtained in column B under the unstandardized coefficients depict the magnitude and the direction of the effect of each variable on the dependent variable, utilization. Observing the value for service quality as 0.300 illustrates that the variable service quality has a moderately strong positive relationship with electronic banking utilization. According to the table, service quality, user inputs, and individual factors positively correlate with utilization, where individual factors share the most robust relationship. The remaining variables depict negative relationships, whereas the perceived risk has the lowest strength, making it the most negligible factor affecting electronic banking utilization consumer choice.

In the scatter plot, standardized residuals and standardized predicted values have been plot (see figure 3). All the residuals are randomly distributed without any predictable pattern. Therefore the residuals do not have a heteroscedasticity problem. According to the normality test of residuals, the researcher applied the Kolmogorov-Smirnov test and Shapiro-Wilk test. The P-value of Kolmogorov-Smirnov test is 0.2 while P-value of Shapiro-Wilk test is 0.514 . Both are insignificant at the five percent and residuals are normally distributed. The result is presented below.(see table 10). 
Figure III. Scatter plot

Scatterplot

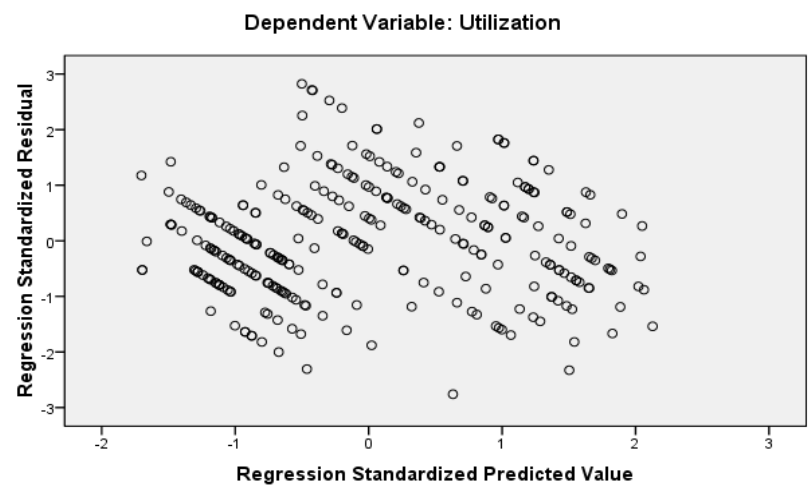

Table X. Tests of Normality

\begin{tabular}{|c|c|c|c|c|c|c|}
\hline \multicolumn{8}{|c|}{ Tests of Normality } \\
\hline & \multicolumn{2}{|c|}{ Kolmogorov-Smirnov ${ }^{\mathrm{a}}$} & \multicolumn{3}{c|}{ Shapiro-Wilk } \\
\hline & $\begin{array}{c}\text { Statis } \\
\text { tic }\end{array}$ & df & Sig. & $\begin{array}{c}\text { Statis } \\
\text { tic }\end{array}$ & df & Sig. \\
\hline $\begin{array}{c}\text { Standardized } \\
\text { Residual }\end{array}$ & .039 & 300 & $.200^{*}$ & .995 & 300 & .514 \\
\hline a. Lilliefors Significance Correction & & & & \\
\hline \multicolumn{3}{|c|}{ This is a lower bound of the true } \\
significance.
\end{tabular}

\section{FINDINGS AND CONCLUSION}

The study's findings reveal that service quality, perceived risk, service product characteristics, price factor, user input factors, and individual factors are significant determinants for the utilization of electronic banking facilities provided by the public banks in Sri Lanka. Further, it reveals the positive relationship between service quality, user input factors, and individual factors with the utilization of electronic banking facilities. There is a negative relationship between price factor, perceived risk, and service product characteristics with electronic banking utilization. Based on their sensitivity to the utilization of electronic banking facilities, the determinant factors were ordered as follows,

1. Individual factors

2. Service quality

3. User input factors

4. Price Factor

5. Service product characteristics

6. Perceived risk

\section{Discussion}

The study's findings show a consistency in the previous literature ( Liao \& Cheung, 2002; Gerrard \& Cunningham, 2003. Alalwan, Dwivedi \& Rana, 2017) related to service quality that it is having a positive relationship with electronic banking utilization. Considering user input factors, the positive relationship between user input factors and utilization shows consistency with previous literature findings (Guracech \& Gregory, 2013; Hernandez, Jonker \& Kosse, 2017; Frame, Wall \& White, 2018). The price factor has negative beta values of -0.117 . It indicates that there is a negative relationship between price factor and utilization of electronic banking facilities. It is supported by Sathye (1999), Alalwan, Dwivedi \& Rana (2017). According to the results obtained by the study, service product characteristics have a negative beta value of -0.109 , which indicates a negative relationship with electronic banking utilization. It shows inconsistent findings from previous literature. (Polatoglu and Ekin, 2001; Gan et al., 2006; ). When it comes to individual factors, it is identified as the most impacting factor on the utilization of electronic banking facilities showing consistency with the previous literature. (Yu, 2015; Asongu, Nwachukwu \& Aziz, 2018; Lin \& Fu, 2018; Changchit et al., 2020). As the most negligible impacting factor, perceived risk has a negative relationship with the dependent variable showing the similarities of Marakarkandy, Yajnik, \& Dasgupta, 2017; Marafon, Basso, Espartel, de Barcellos, \& Rech, 2018.

\section{Limitations}

The study has some limitations. The study was carried out to identify determinant factors of the utilization of electronic banking facilities providing by public banks. Even the sample covers the customers of all public banks. It does not include customers of private banks, including foreign banks. Throughout the study, using the regression model, lit examines the impact of those factors on electronic banking utilization. Nevertheless, several determinants affect the utilization of electronic banking other than the factors mentioned in the model.

Implications According to the findings, Individual factors have the most significant impact on electronic banking utilization. It means that the recourses customers have and their lifestyle would be the most sensitive factors in utilizing electronic banking facilities. Under consumer resources, factors like accessibility to a computer and accessibility to the internet and the easiness of usage have been considered. Even the bank cannot provide such facilities individually for their customers; they can implement more access to the banking network through ATM facilities to increase electronic banking utilization. Implementing more ATM s should be taken into consideration. The second most significant factor in utilizing electronic banking facilities is service quality dimensions. Factors as reliability, assurance and responsiveness were identified under service quality dimensions in this study. To increase the reliability of banking facilities accuracy of the transactions should be increased. At that point, policymakers should implement several rules and regulations to increase the reliability of banking facilities. Considering the service product characteristics as a determinant factor, findings of the study show a negative relationship between service product 
characteristics and electronic banking utilization it implies that still, people did not believe in service product characteristics like consistency standards of facilities, time savings, and the variety of those features that easily enable them to do their banking transactions. On that point, the bankers should consider promoting the advantages of service product features of electronic banking facilities.

\section{Recommendations for further researchers}

The findings of this study provide hints for the people who are interested in doing researches, especially in the banking sector. There can be several determinants that impact the utilization of electronic banking. Research to identify other factors that influence electronic banking utilization would benefit the banking stakeholders. According to the study's findings, Service quality and individual factors impact electronic banking utilization. Higher the reliability, assurance, and responsiveness increase the tendency to utilize electronic banking facilities. Consumer resources availability and favorable consumer lifestyle make customers more familiar with electronic banking facilities. Investigating the impact of those sub factors individually on service quality and individual factors would support stabilizing the highly significant positive impact of service quality and individual factors on electronic banking utilization.

\section{REFERENCES}

[1] Agwu, E. M. (2016). Empirical determinants of consumers' uptake of electronic banking in selected states of Nigeria. West African Journal of Industrial and Academic Research, 16(1).

[2] Alalwan, A. A., Dwivedi, Y. K., \& Williams, M. D. (2016). Customers' intention and adoption of telebanking in Jordan. Information Systems Management, 33(2), 154-178.

[3] Alalwan, A. A., Dwivedi, Y. K., Rana, N. P., \& Williams, M. D. (2016). Consumer adoption of mobile banking in Jordan: Examining the role of usefulness, ease of use, perceived risk and self-efficacy. Journal of Enterprise Information Management.

[4] Amin, M. (2016). Internet banking service quality and its implication on e-customer satisfaction and e-customer loyalty. International journal of bank marketing

[5] Alalwan, A. A., Dwivedi, Y. K., \& Rana, N. P. (2017). Factors influencing adoption of mobile banking by Jordanian bank customers: Extending UTAUT2 with trust. International Journal of Information Management, 37(3), 99-110.

[6] Alalwan, A. A., Dwivedi, Y. K., Rana, N. P., \& Algharabat, R. (2018). Examining factors influencing Jordanian customers' intentions and adoption of internet banking: Extending UTAUT2 with risk. Journal of Retailing and Consumer Services, 40, 125138.

[7] Asad, M. M., Mohajerani, N. S., \& Nourseresh, M. (2016). Prioritizing factors affecting customer satisfaction in the internet banking system based on cause and effect relationships. Procedia Economics and Finance, 36, 210-219.

[8] Asongu, S. A., Nwachukwu, J. C., \& Aziz, A. (2018) Determinants of mobile phone penetration: Panel threshold evidence from Sub-Saharan Africa. Journal of Global Information Technology Management, 21(2), 81-110.

[9] Babić Rosario, A., Sotgiu, F., De Valck, K., \& Bijmolt, T. H. (2016). The effect of electronic word of mouth on sales: A metaanalytic review of platform, product, and metric factors. Journal of Marketing Research, 53(3), 297-318.

[10] Bateson, J. E. (1985). Self-service consumer: An exploratory study. Journal of retailing.
[11] Block, C. E., \& Roering, K. J. (1976). Essentials of consumer behavior. Dryden Press.

[12] Boruah, A. (2018). The Effect of E-Banking on Customer Satisfaction: Evidence from Banking Sector of India. International Journal of Business \& Engineering Research, 11.

[13] Byers, R. E., \& Lederer, P. J. (2001). Retail bank services strategy: a model of traditional, electronic, and mixed distribution choices. Journal of Management Information Systems, 18(2), 133156.

[14] Changchit, C., Klaus, T., Lonkani, R., \& Sampet, J. (2020). A cultural comparative study of mobile banking adoption factors. Journal of Computer Information Systems, 60(5), 484-494.

[15] Chiu, C. M., Chang, C. C., Cheng, H. L., \& Fang, Y. H. (2009). Determinants of customer repurchase intention in online shopping. Online information review.

[16] Clow, K. E., Baack, D., \& Fogliasso, C. (1998). Reducing perceived risk through advertising service quality cues. Journal of Professional Services Marketing, 16(2), 151-162.

[17] Cool, C., \& Xie, H. (2000, November). Patterns of information use, avoidance and evaluation in a corporate engineering environment. In PROCEEDINGS OF THE ANNUAL MEETINGAMERICAN SOCIETY FOR INFORMATION SCIENCE (Vol. 37, pp. 462-472). Information Today; 1998.

[18] Churchill Jr, G. A. (1979). A paradigm for developing better measures of marketing constructs. Journal of marketing research, 16(1), 64-73.

[19] Davidow, W. H. (1986). Marketing high technology. Simon and Schuster.

[20] Dewey, J. (1910). How we think. New York, NY: DC Health. Online version.

[21] Elliott, R. H., Rosenbaum-Elliott, R., Percy, L., \& Pervan, S. (2015). Strategic brand management. Oxford University Press, USA.

[22] Engel, J. F., Kollat, D. T., \& Roger, D. (1973). Blackwell, consumer behavior. New York.

[23] Falkovitch, O. (2020). FACTORS THAT ENCOURAGE AND DISCOURAGE THE ADOPTION OF ONLINE BANKING IN ISRAEL AND THEIR EFFECT ON CUSTOMER SATISFACTION, FROM THE POINT OF VIEW OF BANK MANAGERS. SEA: Practical Application of Science, 8(2).

[24] Firdous, S., \& Farooqi, R. (2017). Impact of internet banking service quality on customer satisfaction. The Journal of Internet Banking and Commerce, 22(1), 1-17.

[25] Frame, W. S., Wall, L. D., \& White, L. J. (2018). Technological change and financial innovation in banking: Some implications for fintech.

[26] Gan, C., Clemes, M., Limsombunchai, V., \& Weng, A. (2006). A logit analysis of electronic banking in New Zealand. International Journal of Bank Marketing.

[27] Gerrard, P., \& Cunningham, J. B. (2003). The diffusion of internet banking among Singapore consumers. International journal of bank marketing.

[28] Giannakoudi, S. (1999). Internet banking: the digital voyage of banking and money in cyberspace. Information and Communications Technology Law, 8(3), 205-243.

[29] Guracech, g., \& Gregory, D. (2013, August 20). BAI banking strategies. Retrieved from BAI organization web site https://www.bai.org

[30] Hampshire, C. (2017). A mixed methods empirical exploration of UK consumer perceptions of trust, risk and usefulness of mobile payments. International Journal of Bank Marketing.

[31] Hernandez, L., Jonker, N., \& Kosse, A. (2017). Cash versus debit card: The role of budget control. Journal of Consumer Affairs, 51(1), 91-112.

[32] Hendrikse, M. D. F., \& Christiaanse, E. (2000). Mobile Commerce: An Exploratory Study on Impacts in Mobile Services. PrimaVera Working Paper, (25).

[33] Hussien, M. I., \& Abd El Aziz, R. (2013). Investigating e-banking service quality in one of Egypt's banks: a stakeholder analysis. The TQM Journal. 
[34] Islam, H., Jebarajakirthy, C., \& Shankar, A. (2021). An experimental based investigation into the effects of website interactivity on customer behavior in on-line purchase context. Journal of Strategic Marketing, 29(2), 117-140.

[35] Karjaluoto, H., Mattila, M., \& Pento, T. (2002). Electronic banking in Finland: consumer beliefs and reactions to a new delivery channel. Journal of financial services marketing, 6(4), 346-361.

[36] Khan, M. A., Zubair, S. S., \& Malik, M. (2019). An assessment of e-service quality, e-satisfaction and e-loyalty. South Asian Journal of Business Studies

[37] Liao, Z., \& Cheung, M. T. (2002). Internet-based e-banking and consumer attitudes: an empirical study. Information \& management, 39(4), 283-295.

[38] Liébana-Cabanillas, F., Sánchez-Fernández, J., \& Muñoz-Leiva, F. (2014). The moderating effect of experience in the adoption of mobile payment tools in Virtual Social Networks: The m-Payment Acceptance Model in Virtual Social Networks (MPAMVSN). International Journal of Information Management, 34(2), 151-166.

[39] Lin, C. F., \& Fu, C. S. (2018). Implications of integrating e-leisure constraints and means-end hierarchies of young people's perceptions toward video-sharing websites. Online Information Review.

[40] Ling, G. M., Fern, Y. S., Boon, L. K., \& Huat, T. S. (2016). Understanding customer satisfaction of internet banking: A case study in Malacca. Procedia Economics and Finance, 37, 80-85.

[41] Lockett, A., \& Littler, D. (1997). The adoption of direct banking services. Journal of marketing management, 13(8), 791-811.

[42] Loundon, D.L. and Bitta, A.J.D. (1993), Consumer Behavior: Concepts and Applications, 4th ed., McGraw-Hill Irwin, New York, NY.

[43] Mantel, B. (2000). Why don't consumers use electronic banking products? towards a theory of obstacles, incentives, and opportunities. Towards a Theory of Obstacles, Incentives, and Opportunities (September 2000).

[44] Marafon, D. L., Basso, K., Espartel, L. B., de Barcellos, M. D., \& Rech, E. (2018). Perceived risk and intention to use internet banking. International Journal of Bank Marketing.

[45] Marakarkandy, B., Yajnik, N., \& Dasgupta, C. (2017). Enabling internet banking adoption. Journal of Enterprise Information Management.

[46] Mols, N. P. (1998). The internet and the banks' strategic distribution channel decisions. Internet Research.
[47] Mudie, P., \& Pirrie, A. (2012). Services marketing management. Routledge.

[48] Polatoglu, V. N., \& Ekin, S. (2001). An empirical investigation of the Turkish consumers' acceptance of Internet banking services. International journal of bank marketing.

[49] Prakash, G. (2019). Understanding service quality: insights from the literature. Journal of Advances in Management Research, 16(1), 64-90.

[50] Pyun, C. S., Scruggs, L., \& Nam, K. (2002). Internet banking in the US, Japan and Europe. Multinational Business Review, 10(2), 73-73.

[51] Safeena, R., Kammani, A., \& Date, H. (2018). Exploratory study of internet banking technology adoption. In Technology adoption and social issues: Concepts, methodologies, tools, and applications (pp. 333-355). IGI Global.

[52] Šalčiuvienè, L., Auruškevičienè, V., \& Ivanauskienė, N. (2014). Key drivers affecting customer intention to purchase financial services online. Inžinerinè ekonomika, 25(2), 194-202.

[53] Sathye, M. (1999). Adoption of Internet banking by Australian consumers: an empirical investigation. International Journal of bank marketing.

[54] TABASH, M. I., ALBUGAMI, M. A., SALIM, M., \& AKHTAR, A. (2019). Service quality dimensions of E-retailing of Islamic banks and its impact on customer satisfaction: An empirical investigation of kingdom of Saudi Arabia. The Journal of Asian Finance, Economics, and Business, 6(3), 225-234.

[55] Yi, Zainuddin \& Bakar, 2021). Conceptual Model on Internet Banking Acceptance in China with Social Network Influence. JOIV: International Journal on Informatics Visualization, 5(2), 177-186.

[56] Yu, C. S. (2015). Using e-lifestyle to analyze mobile banking adopters and non-adopters. Journal of Global Information Technology Management, 18(3), 188-213.

[57] Zeithaml, V. A. (1981). How cdnsuper evaluation processes dlffer between goods and serveces. In Conference: American Marketing Association First Services Marketing Conference.

[58] Zhao, A. L., Hanmer-Lloyd, S., Ward, P., \& Goode, M. M. (2008). Perceived risk and Chinese consumers' internet banking services adoption. International Journal of Bank Marketing.

[59] Zhu, Z., Nakata, C., Sivakumar, K., \& Grewal, D. (2013). Fix it or leave it? Customer recovery from self-service technology failures. Journal of Retailing, 89(1), 15-29. 